\title{
COVID-19 Worries and Opportunities
}

\author{
Sabra Zizi E. I. $^{1}$
}

${ }^{1}$ Fayoum University, Egypt

Received: 23.11.2020; Accepted: 15.12.2020; Published: 20.12.2020

$\begin{array}{rll}\text { Keywords: } & \text { COVID-19, pandemic, psychology, health, social distance } \\ \text { Copyright: } & \begin{array}{l}\text { C } 2020 \text { Sabra Zizi E. I. Published by Archives of International Journal of Science } \\ \text { Annals }\end{array} \\ \text { DOI and UDC } & \text { DOI 10.26697/ijsa.2020.2.6; UDC 159.9:316.6:614.441 } \\ \text { Conflict of interests: } & \text { The author declares that there is no conflict of interests } \\ \text { Source of support: } & \text { This study did not receive any outside funding or support } \\ \text { Information about } & \begin{array}{l}\text { Sabra Zizi Elsayed Ibrahim - https://orcid.org/0000-0001-8329-9615; } \\ \text { the author: } \\ \text { zss11@fayoum.edu.eg; Doctor of Philosophy in Psychology, Associate Professor, } \\ \text { Department of Psychology, Faculty of Arts, Fayoum University, Fayoum, Egypt. }\end{array}\end{array}$

\section{Dear Editor,}

With the middle of March 2020 the news of breakout of the pandemic had been assured around the world, spreading the uncertainty and worry in a very ambiguous atmosphere all over the world (World Health Organization, 2020b). World health organization with the group of 20 (G-20) and United Nations (UN) at 26 of March 2020 committed collaboration in facing the pandemic (Khashaba, 2020).

All countries including Egypt worked according to the recommendation of the World health organization plan in facing this pandemic, taking into account the safety rules in all sectors of the society (World Health Organization, 2020a) up to date efforts to help control and manage the COVID-19 and NCOVID-19. As a part of Information and Decision Support Center - Egyptian Cabinet keenness on spreading public opinion awareness, the center is publishing a newsletter about the implications of the new Corona-Virus, with the purpose of presenting the latest updates on the international level, and the most important measures and initiatives that can be of benefit in health sector, education sector, professions and social sectors too (Information and Decision Support Center System, 2020) side to side with the Regional and international efforts (Madoui \& Bendjeroua, 2020' Namsolleck \& Moll, 2020).

Although of having hard time and big challenges to protect ourselves and loved ones, it is always possible to keep a positive mindset and stay resilient. When we look back to the last eight months we will find out how every one of us had the opportunity to test his will power to continue our achievements in education, profession, social, health fields. We could notice how connected is world and how we are able to manage issues as one team. We can notice the millions of creative plans and problem solving techniques to keep our daily life activities with the most balanced way. We have the Right to feel frustrated, feel irritated or depressed during the uncertainty time, and the facts proved that we can manage things well in spite of that. The impact of medical and psychological support in the pandemic COVID-19 situation was studied (Melnyk \& Stadnik, 2020).

The most important part is that you have the right to get help dealing with these feelings, and enhance your immune system by keeping your positive mindset. Some psychological tips could help reducing your hyper vigilance and help you enjoy your life. Simply, instead of thinking of what you cannot do think of things that you can do. First thing to do is not isolating yourself, meet people and keep the social distance, wear masks, and enjoy laughing together in the fresh air. This is going to make you more resilient, isolating your self could be harmful to you and your health. Resilient people try to reevaluate the situation and make the positive new list of goals. Resilient people are flexible and it helps to modify and comfy your expectations to make you feel better about what is available and how it could be done (Naseem \& Khalid, 2010).

Second, plan your day a head and keep a schedule to follow. Having a "to do list" help you setting your anxiety aside and feel the power of productivity. try to make your schedule fit the whole week achievements, or even set a month plan a head, make it an obligation to yourself, don't forget to have fun achieving your goals. Third, stay connected with your social network, connectedness is cure and keep you feel well. All paths are accepted for connecting with others, including texting, calls, tele-conferences, sharing experiences, coplanning activities, the list is open to your creative mind. Life is generous and always gives us the opportunities to grow wisdom and more acceptance and commitments to stay efficient and happy at the same time. 


\section{Acknowledgements}

I would like to express my deepest gratitude to Dr. Yuriy Melnyk for introducing this prestigious Journal to me and encouraging me to publish my letter in the aforementioned Journal.

\section{References}

Information and Decision Support Center System. (2020). New Coronavirus implications (COVID19). Retrieved from https://www.idsc.gov.eg/IDSC/DocumentLibrar y/View.aspx?id=4327

Khashaba, M. M. (2020). Concepts and contexts in COVID-19 crises. Retrieved from http://repository.inp.edu.eg/xmlui/handle/12345 6789/4833 [in Arabic]

Leahy, R. (2020). Re: A road map to finding calm amid coronavirus anxiety [Newsletter message]. Retrieved from https://healthmatters.nyp.org/aroad-map-to-finding-calm-amid-coronavirusanxiety/

Madoui, A., \& Bendjeroua, H. (2020). Activating virtual tourism to animate the tourist destinations in light of the emerging Corona Virus crisis Covid-19: with reference to the case of Algeria.
Management \& Economics Research Journal, 2(2Special), 50-63. doi:10.48100/merj.v2i2Special.101 [in Arabic]

Melnyk, Yu. B., \& Stadnik, A. V. (2020). Medical and psychological support to specialists under conditions of pandemic COVID-19. Minerva Psichiatrica, 61(3), 109-112. doi:10.23736/s0391-1772.20.02083-X

Namsolleck, P., \& Moll, G. N. (2020). Does activation of the protective Renin-Angiotensin System have therapeutic potential in COVID-19? Molecular Medicine, 26, 80. doi:10.1186/s10020-02000211-0

Naseem, Z., \& Khalid, R. (2010). Positive thinking in coping with stress and health outcomes: Literature review. Journal of Research and Reflections in Education, 4(1), 42-61.

World Health Organization. (2020a). Timeline: WHO's COVID-19 response. Retrieved from https://www.who.int/

World Health Organization. (2020b). WHO DirectorGeneral's opening remarks at the media briefing on COVID-19 - 2 November 2020. Retrieved from https://www.who.int/

\section{Cite this article as:}

Sabra, Z. E. I. (2020). COVID-19 Worries and Opportunities. International Journal of Science Annals, 3(2), 36-37. doi:10.26697/ijsa.2020.2.6

The electronic version of this article is complete. It can be found online in the IJSA Archive https://ijsa.culturehealth.org/en/arhiv and in the KRPOCH Publishing Repository https://ekrpoch.culturehealth.org/handle/lib/71 This is an Open Access article distributed under the terms of the Creative Commons Attribution License, which permits unrestricted use, distribution, and reproduction in any medium, provided the original work is properly cited (http://creativecommons.org/licenses/by/4.0/deed.en). 